\title{
Problematizing the context and construction of vulnerability and risk in relation to British Muslim ME groups
}

\author{
Sara Ashencaen Crabtree, PhD
}

Faculty of Health \& Social Sciences, Bournemouth University, Bournemouth, United Kingdom

\begin{abstract}
British Muslim minority ethnic (ME) groups are perceived as holding values and beliefs distinctively different from the rest of multicultural UK. Vulnerability in these groups relates to existing material and social conditions and is contrasted to the perceived risks to British society and the State posed by religio-ethnic separatism. Such dichotomies create new textures and layers to familiar but complex concepts of vulnerability in social work. The problematization of British ME Muslims in public discourse and related social policy are critically discussed as contributing to a fluid but potentially inflammatory terrain where vulnerability and oppression are highly ambiguous and contested.
\end{abstract}

\section{ARTICLE HISTORY}

Received 30 June 2016

Accepted 23 February 2017

\section{KEYWORDS}

British Muslim; counterterrorism; marginalization; minority ethnic; vulnerable

\section{Introduction}

This article offers a discursive analysis of the perceived problematization of British Muslim minority ethnic (ME) communities as standing apart from majority normative values and beliefs, including the ideals of integrated multiculturalism in the UK. This perception is considered in terms of the context of socioeconomic and material conditions affecting such communities; and where issues and concepts of vulnerability, perceived and actual, are explored as complex, ambiguous, and multidimensional. This, in turn, foregrounds an examination of the perceived risks of wide-scale radicalization of Muslim youths along with a critique of the rationale and implementation of counterterrorist measures aimed at tackling such threats. The implications for social workers working with marginalized ME groups and operating in contested sociopolitical terrain are duly considered in an attempt to raise the implications of issues and concepts for further dialogue. Specific recommendations to social workers are avoided in this article, as being inappropriately suggestive of one hegemonic interpretation of social work in a context that is clearly multiply nuanced and formidably complex.

CONTACT Sara Ashencaen Crabtree, PhD scrabtree@bournemouth.ac.uk E Faculty of Health \& Social Sciences, 2nd Floor, Royal London House, Bournemouth University, Christchurch Road, Bournemouth, BH1 3LT, United Kingdom. 
This article was written against a carnage of terrorist strikes during 2016. The "copycat" massacre of festival shoppers at a Christmas market in Berlin (Spiegel Online, 2016), followed on the heels of the shocking massacre of 84 people on Bastille Day in Nice (Christafis, Fischer, \& Oxley-Rice, 2016). This, in turn, arrived on the aftermath of an attack on a gay nightclub in Florida by a gunman. In each case the individual, although probably acting as a disturbed, lone maverick, was said to claim allegiances to the "Islamic State of Syria and Levant" (ISIS/Daesh).

To add to this catalogue of atrocities the previous year witnessed the appalling bombing of hundreds of Parisians by Daesh gunmen and suicide bombers (BBC, 2015). These acts of Islamist violence also include the London bombings (7/7), the Madrid bombings of 2004 and 9/11 bombings. Nor must we forget the bombings of Istanbul and Bali, as well as the kidnap and sexual exploitation of Nigerian schoolgirls by the Muslim insurgency group, Boko Haram.

All such momentous terrorist attacks act as bloody exclamation marks on the pages of international relations and relate directly to extremist interpretations of Islam, commonly referred to as "Islamist" rather than "Islamic." This is an important distinction to make, where the latter refers to religious doctrine together with precepts and principles underpinning the faith. In this article the former term "Islamist" is defined as denoting aggressive supremacist ideologies based on faith identification. However, the potential conflation of the two terms "Islamic" and "Islamist" underlines the social dynamics of a destructive xenophobic discourse that serves to both alienate and oppress Muslims living as minority groups in the Global North. In this article we examine how this is played out in the UK in terms of material realities and social policy. We consider the problematization of British Muslims as a minority group, as well as exploring actual and potential responses by UK social work responses.

The penetrating gaze of sociopolitical and media surveillance has fallen heavily upon Muslim ME communities across much of the Northern Hemisphere in the fallout of these events. While civil and armed conflict in the Middle East and ethno-religious insurgency groups in African nations creates the public perception in the West of a regional loci of fanatical destruction and benighted chaos spilling over into the "tidy" regions of the "civilized" world. Additionally, to many across the Global North, we are living through a brief period of history of alarming political reverberations on the home front. Heightened civil tensions in the escalation of expressed intolerance and indeed, outward xenophobia, toward those regarded as different or alien are served by a fantasy (or orthodoxy) of homogenized nation states rather than plural and heterogeneous multiculturalism.

Internationally, the igniting of conflagrations by invasion and creation of unstable power vacuums through the politico-aggressive interference of 
Western nations, deposing some inconvenient tyrants or insurgency groups, while deliberately or inadvertently creating others, is an issue consistently played down in political arenas, where a rhetoric of liberation and democratization has dominated. The chosen combined approach of armed "peacekeeping" and a pedagogic diet of so-called "Western values" (democracy, capitalism, human rights, and so on) suggested by the "winning hearts and minds" formula is often interpreted quite differently in receiving countries, both at the ground level of ordinary people and among political factions seeking power-bases (Ashencaen Crabtree \& Williams, 2011). The "glocal" influence of such perceptions play out within communities and social spaces as well, shaping experiences of social integration or social exclusion and alienation. These carry resonances for social workers working within multicultural societal contexts in relation to encounters with service user groups, some of whom will be Muslims, and where likely unfamiliarity with the faith and problematization of Muslims may color encounters.

\section{Demographics, material realities, and "vulnerability"}

"Vulnerability" within social work vernacular frequently relates to general and codified social work values and ethics, and their enactment by professionals. Those that are invulnerable, if such could be, hardly require social work intervention. Social work deals directly with those who experience levels and forms of vulnerability. However, this is not to overlook that firstly, all people can experience vulnerability and that it also a politicized issue. In UK social work "vulnerability" is used as a form of classifying individuals into categories of criteria eligible for social service provision (Penhale \& Parker, 2008). Those in receipt of care in a residential or nursing home, or those who receive personal care from domiciliary care agency, or those receiving medical services are viewed as "vulnerable"-and thus may be eligible for social work intervention (Care Standards Act, 2000).

Used to construct eligibility for services, this usage of the term "vulnerable" conveys a political discourse of power. More evidently, vulnerability may occur in relation to life events and experiences. Controversially too, those that society views as enacting or being capable of enacting harm against others, may themselves experience vulnerability. A construction of immigrants and/or minority groups that are viewed as self-segregated from majority society norms and life styles can also be those that occupy the apparent polarity of being both the oppressive and the oppressed.

The UK has had a long history of receiving migrants over the centuries (Modood et al., 1997). However, in reference to the 20th century, many economic South Asian Sunni Muslim migrants from the Kashmir area of Pakistan settled in the manufacturing industries in the North of England (Peach, 2006). The expulsion of Asian Muslims from Uganda by the 
murderous dictator, Idi Amin, brought in an influx of displaced Muslim people in the 1970s, in addition to other African countries. In the 1980s Bangladeshi migrants entered the country as economic migrants, although increasing ethnic heterogeneity of Muslim migrants appears to be the current trend (Ashencaen Crabtree, Husain, \& Spalek, 2008).

In the course of one decade (2001 to 2011) Census data shows that the Muslim population in the UK has doubled in size, standing now at $4.8 \%$ of the entire population of England and Wales (Ashencaen Crabtree, Husain, \& Spalek, 2016; MCB, 2015). Scotland currently boasts 77,000 Muslims and there are nearly 4,000 Muslims living in Ireland. The British Muslim population is characterized by youth, where 33\% of British Muslims are aged 15years-old or under. The demographics have also altered in terms of ethnicity, where Census data recording Muslim ethnic categories reveal that "Black African, Black other" and "Asian other" are growing, while the Pakistani and Bangladeshi figures are falling (MCB, 2015).

For several years, demographic trends have shown that British Muslims occupy the lowest rungs of socioeconomic standing among all faith groups in the UK (TUC, 2005). The 2001 National Census revealed Muslims as experiencing poorer housing conditions, with inadequate heating, as well as greater levels of overcrowding, where $42 \%$ of Muslim children lived in overcrowded accommodations compared to $12 \%$ of the overall population. Moreover, $35 \%$ of Muslim children lived in households where no adult was in employment, compared to $17 \%$ of the general population (Ashencaen Crabtree et al., 2008; ONS, 2002).

The implications of general underprivilege among British Muslim families might have been more clearly apparent to the UK social work profession had the move from community-based, generic social work "patches" not taken place. Changes in social work saw the fragmentation of community social work intervention into the organization of social workers into particular professional teams dedicated to specific areas of need (Orme, 2001). The ideological and efficiency drive behind changes to social work provision also altered the holistic panorama that in theory community social work afforded to local families struggling with intersectional oppressions (Hill Collins, 1998).

The picture for British Muslims since the early 2000s has not changed significantly in the UK. Heath and Li (2014) report the polarity across faith groups in terms of poverty, irrespective of ethnicity, where British Muslims are most likely to live in poverty and the Jewish community the least likely.

If, arguably, the road out of cyclical poverty is based largely on education and social mobility, then it is encouraging to see that there have been some improvements for such families. Based on the latest Census figures, data mining by the Muslim Council of Great Britain (MCB) reveals that one quarter of young Muslims are educated to degree level, marginally below 
the national level, compared to the statistic in the previous census where a quarter of Muslims had no qualifications at all. This said, British Sikhs and Hindus, as a comparator group, have a higher level in terms of overall qualifications (Muslim Council of Great Britain [MCB], 2015).

By contrast the socioeconomic conditions for Muslims in the United States appears to be more favorable overall than for British Muslims, in terms of affluence and social mobility (McAskill, 2007). These contrasts are the result of different starting points relating to class as well as educational factors. For while the U.S. visa system prioritized entry for skilled and educated economic Muslim migrants, unskilled migrants from rural and/or impoverished regions were permitted entry to the UK and wider Europe to fill an acute post-War labor gap (Ashencaen Crabtree et al., 2016).

\section{Islamophobia and identity formation}

Conditions of endemic underprivilege may be responded to by those that experience them in a variety of ways, including passive "learned helplessness" or active resistance, whether constructive or destructive. In an early analysis Archer (2003) claimed that young British Muslim men could react against the perceived weakness of the category "Asian" (replete with orientalist stereotypes of inferiority and passivity) by constructing a "strong" Islamic identity for themselves and an extreme example of this can be observed in the now equally pervasive stereotype of the black masked "jihadist warrior" AKA gun at the ready. In this vein, 7/7 London bomber, Mohammed Siddique Khan filmed himself "doing masculinity" justifying the forthcoming terrorist attack, as a job for "real men-the true inheritors of the Prophet" (Archer, 2003; Ashencaen Crabtree et al., 2008 p. 3).

Essentializing gender constructions with the potential for oppressive or harmful repercussions to wider society has been considered by the profession, for example, through feminist social work (Dominelli, 2002) in terms of domestic violence and child protection work (Scourfield \& Coffey, 2002). However, finding examples, of direct social work practice, with ME male youth on gendered, sociocultural constructions of masculinity or patriarchal values remain rare. Accordingly, Germany's social pedagogic social work approach offers an interesting example through the "Projekt Heroes" training programs with immigrant Muslim youths, reflecting on gendered norms and violence with a view to the participants sharing new/altered ideas within their own communities (Schuster-Craig, 2015).

In reference to Islamophobic discrimination in Europe, Fleischmann and colleagues (2011) discuss the malign influence of perceived discrimination in shaping identities and life courses. Accordingly, subjective experiences of Islamophobia are likely to push second-generation migrants on a trajectory toward adopting a strong religious identity compared to the reactions of the 
previous generation. This rebirth into a robust Islamic identity to counter perceived oppression has the inherent potential of leading to direct political action (Ashencaen Crabtree, 2014). The repercussions of social and civil conflict normally implicate social work in terms of responding to trauma at the micro- and meso-levels of impact. However, in relation to terrorism, although in Britain social work carries a professional remit here, there is a knowledge gap on actual intervention (Parker \& Ashencaen Crabtree, 2014), an issue also raised by Guru (2012), as will be discussed.

Islamophobia as a form of discrimination carries obvious discordant resonances for social work given its overt antidiscriminatory, antioppressive value base. However, it is not an uncontested term being ambiguously defined. The term itself came into wider currency with the UK Runnymede Report of 1977 entitled Islamophobia: A Challenge for Us All, which set out some key characteristics denoting this form of discrimination, including assumptions of Islam as monolithic and static; separate and "other" in terms of values; an inferior culture; aggressiveness and manipulative; critical of the West and where patriarchy and sexism is endemic (Runnymede Trust, 1997). To this list Taras (2013) adds the additional Islamophobic beliefs of Muslims as irrational and that Islamic ideology is used for political and military agendas (presumably meaning as a rule rather than as an exception); consequently deserving of social exclusion and, thus, normalizing antipathy toward Muslims.

Even with this list of characteristics to hand, the hunt for an agreed definition has still proved elusive. For Islamophobia is neither solely prejudice against ethnicity nor religious affiliation (Lorente, 2010), but something more of a shifting chimera (Hussain and Bagguely, 2012). Instead Grosfoguel and Mielants (2006) describe Islamophobia as one of the new racisms where cultural racism (viewed as alien to and incompatible with the dominant culture) supersedes biological racism as prejudice against "race"/ ethnicity. In fact Taras following Tariq Modood, goes on to further refine Islamophobia as "Muslimophobia" whereby such prejudice "bundles religious ethnic and cultural prejudices together, just as anti-Semitism ... does" (Taras, 2013, p. 425).

However, it being defined Islamophobia would appear to be sharply on the increase across Europe, North America, and Australia (Bangstad \& Bunzl, 2010; Fleischmann et al, 2011; Frost, 2012; Geisser, 2010; Gündüz, 2010; Hussain \& Bagguley, 2012; Kunst, Tajamal, Sam, \& Ulleberg, 2012; Sheridan, Gillett, Blaauw, \& Winkel, 2003). The election of Donald Trump has aroused a furore of media attention within the United States and internationally, where open animosity toward and rejection of Muslims formed part of the election campaign as evidently appealing to segments of American society. This was earlier mirrored by the UK's European Union (EU) Referendum in June 2016, where the "Leave" "Brexit" (Britain Exit) campaign pivoted largely 
on EU immigration policies (and irrationally, given that such immigration policies refer to the international mobility of EU citizens, not necessarily others), Brexit campaign propaganda particularly targeted immigrants from the Middle East as well as Eastern Europe. A worrying point of comparison between the UK and the United States is that xenophobic hate crimes have risen markedly in the wake of the voting outcomes (Forster, 2016; Yan, Sgueglia, \& Walker, 2016).

The issue of precisely what is and what constitutes Islamophobia remains open to debate, nonetheless, it is a term with powerful resonances. Malik argues that the accusation of "Islamophobia" is used to censor and stifle debate. Moreover, Lorente (2010, p. 117) probes the ambiguities in the construction of "Islamophobia," concluding that it acts as a "universal container of social practices and meanings." In other words, perceptions and subjective experiences may be construed as such and responded to accordingly. For younger generations of Muslims who live in what used to be referred to as migrant receiving "host countries," such views may be the impetus for decreasing rather than increased levels of social engagement and participation in civil society and the search for alternative identities (Ashencaen Crabtree et al., 2016). Nonetheless, the appointment of the first Muslim Mayor of London, Sadiq Khan, in May 2016 was widely seen as a powerful symbolic countermeasure to this trend, where it was triumphantly announced, "It shows it is possible to be Muslim and a westerner. Western values are compatible with Islam" (Malik, 2016).

It is indeed highly significant that in an openly multicultural, modern country like the UK such a statement needed to be made at all; and appears to respond to what appears to be an important rhetorical question in society, perhaps never more so than now.

\section{Vulnerability, multiculturalism and social exclusion}

As argued, the concept of "vulnerability" carries particular connotations and status within the UK (Penhale \& Parker, 2008). Here the term is employed in a wider sense to consider vulnerability as a complex concept that operates at many social and interpersonal levels. For example, perceived racism is a factor regarded as clearly contributory to the vulnerability of mental distress (Fenton \& Sadiq-Sangster, 1996); and so too is Islamophobia, particularly in terms of the public and political backlash, or fear of, following terrorist attacks from Islamist groups (Laird et al., 2007).

Vulnerability, therefore, relates not only to socioeconomic disparities but can also be applied to stigma and social exclusion that stunts potential and injures self-esteem. This is an area that social workers are of course well versed in by virtue of training and practice. Yet what of social exclusion that is problematized as self-imposed? Is there even a 
role for social work in this scenario and if so, what form should it take? These questions are posed in response to a particular feature of some urban areas in the UK with a high South Asian population in respect of a high level of ghettoization of Muslim ME groups. This phenomenon does not seem to be directly linked to poverty and racism (although that possibility should not be dismissed), but could easily be construed as self-imposed as these urban conurbations are otherwise commonly ethnically heterogeneous and socially mixed. Yet despite this urban diversity, small concentrations of homogenized Muslim ME groups may choose to interact and follow their traditional lifestyles almost exclusively within their own ethno-cultural neighborhood milieu (Ashencaen Crabtree, 2014).

Perceived insularity among certain groups viewed as holding markedly different practices to the majority are not of course, confined only to some British Muslims, but others, such as the European Gypsy Roma, British Romany and Traveller groups, have also been targets of government policies, nominally aimed at reducing underprivileged but where the effects are of imposing cultural norms that are alien to such groups (Heaslip, Hean, \& Parker, 2016; Scullion \& Brown, 2016). An example of cultural norms for Roma groups (which superficially echo some of the values of British Muslims as well as that of orthodox Jews), are those that many social workers might find questionable in terms of equality and empowerment. For example, the focus on traditional gendered roles, the value of female chastity and the focus on education of children to uphold community/cultural/religious values over and above those of the dominant cultural group (Scourfield, Warden, GilliatRay, Khan, \& Otri, 2013).

Social segregation acting as a form of social exclusion in wider society can particularly affect ME women who speak little or no English even after years of migration to the UK, and may be almost entirely reliant on their menfolk and children for translation. Former British Prime Minister, David Cameron, focused on this issue by raising the spectre of repatriation of migrant ME women on spousal visas who had failed to learn sufficient English 2 years after immigration (BBC, 2016). This controversial move was widely regarded as aimed at South Asian Muslim ME women entering the country (usually through arranged marriages), whose economic (and civic) participation in society is much lower compared to the general female population (Muslim Council of Great Britain [MCB], 2015).

Although Cameron's comments aroused strong critique, it formed part of the general antiimmigrant rhetoric of recent right-wing politics, where certain British Muslims (over and above any other Black or ME group) were targeted as evidently socially unassimilated and, therefore, as constituting another conspicuous failure of multiculturalism (Grossfoguel \& Mielants 2006; Gündüz, 2010, p. 45). 
In reference to social integration of ME people, there are further implications in relation to domestic violence. This form of abuse, as we know, is not tied to class, ethnicity, and nationality but vulnerability can be heightened for ME women living in ethno-segregated areas where family and community support may be lacking for cultural reasons (Ashencaen Crabtree et al., 2016). Thus, the victim may be additionally victimized and ostracized if she attempts to leave an abusive marriage (Reavey, Ahmed, \& Majumdar, 2006). The UK visa regulations can further aggravate the risks of continued domestic violence by jeopardizing residency rights if women on spousal visas separate from abusive partners (Bucci, 2012) Furthermore, social workers may be confronted by the vexing question of religio-culturally sensitive resources, which are genuinely sensitive to such needs and supports women in their decision making regarding their future, faith issues, and human rights (Faizi, 2001; Pryke \& Thomas, 1998).

Apart from spousal abuse there are of course other forms of domestic violence and some of these are more prevalent in South Asian communities as well as those of Middle Eastern heritage (Tripathi \& Yadav, 2004). These relate to so-called "honor-based violence" (HBV) - an issue of notoriety following the murders of several young British women, as well as being rife internationally, where it is estimated by the United Nations that 5,000 girls and women are murdered each year (http://hbv-awareness.com).

The Islamic notion of izzat (meaning "honor" and/or "respect") is generally used as the religio-ethnic justification among Muslim ME communities, implicated in HBV, to condone and collude with the practice (Reavey et al., 2006). While it may be hoped that attitudes are now changing, a 2006 poll undertaken for the BBC's Asian Network showed that one in 10 young British Asians believed that murders committed in the name of family honor could be justified (BBC, 2006). In this same year the body of a 20-year-old London Kurdish woman, Banaz Mahmood, was found buried in a suitcase after being murdered by family members for falling in love with the wrong suitor (Ashencaen Crabtree et al., 2008).

In the UK domestic violence also includes "forced" (as opposed to "consenting" arranged) marriage (Tickle, 2006). While arranged marriages globally are adapting over time through the recognition of the personal and professional status of young educated adults, in practicing conservative ME communities in the UK, there is frequently an expectation of nonnegotiable compliance (Ashencaen Crabtree et al., 2016). Thus the line between consenting and coerced marriage is a very fine one, where victims may face intense family pressure to comply, which can include serious domestic violence, kidnap, and rape (Anitha \& Gill, 2009).

Another alarming issue has been the appalling recent revelations regarding the scale of sexual exploitation of minors in the North of England, by organized and violent "street grooming" gangs predominantly from ME 
communities. The scandalously numerous victims in these Rotherham and Rochdale cases were described as White, working-class schoolgirls some as young as 11-years-old mostly from troubled and underprivileged backgrounds, who were targeted, raped, and forcibly prostituted by these gangs (CEOP, 2011; Coffey, 2014). The government inquiry into the cases revealed that the girls were viewed by local police and social services as incorrigible and that little could be done to help them (Jay Report, 2014).

These revelations shook complacent notions of what constituted vulnerability and how it should be responded to (Phillips, Goodhart, \& Gower Davies, 2016). The conspicuous cross-ethnic component derived from the fact that offending gangs were made up primarily Pakistani men-a fact that caused a huge amount of liberal-minded agonizing for fear of scapegoating entire ME communities.

However, a different complexion was cast over these cases when the UK Muslim Women's Network produced a report (Gohir, 2013) graphically recording the disclosures of 35 Asian girls, the majority being Muslim, who had experienced almost the same levels of sadistic abuse and exploitation by groups of men from their own communities, where religio-cultural patriarchal had been used to control victims and izzat used as a threat against exposure of crimes. Suddenly it was no longer a case of gross cross-religioethnic dysfunctions but the discovery of the vilest misogyny enacted on vulnerable, young girls irrespective of ethnicity or faith (Ashencaen Crabtree et al., 2016; Gohir, 2013).

The complexity of the dimensions of vulnerability engages the social work profession at various points of intersection in relation to child protection work. In the UK, the focus is largely on safeguarding issues and managing risks to individuals at the microlevel of social interaction and daily living (Turney, Platt, Selwyn, \& Farmer, 2011). The meso-community engagement aspects are disappearing beyond the brief of British practitioners' caseloads and are increasingly falling to the independent sector to tackle. Social work's ability to influence macro social policy is further jeopardized by an increasingly bureaucratized profession that is a hostage to the mandates of a neoliberal political culture antipathetic to adequate welfare provision but highly directive in their interference (Parker \& Bradley, 2014).

Another issue revolves around the issue of social assimilation as opposed to integration, where the former implies a certain homogenization of cultural values and practices regardless of ethnicity or cultural origin. The concept of integration in principle recognizes the rights of people to a distinctive cultural identity, but assumes the upholding of certain sociopolitical values and norms-an altogether trickier terrain to negotiate in practice.

This dilemma was recently aired in a televized UK Channel 4 program featuring Trevor Phillips, the former Chair of the UK Equality and Human Rights Commission, himself from an ME background, who offered a 
discomfiting analysis of the state of multiculturalism in the country later accompanied by a less sensationalized coauthored report, of a BBC poll of 1,000 British Muslims (Phillips et al., 2016). The survey revealed that a fractionally higher proportion of Muslims feel a stronger sense of belonging to Britain than the national average and also regarded the UK is a good place to live for Muslims. However, attitudes toward other values appeared to differ markedly from that of the general population. For example, nearly a quarter of British Muslim participants wished to see sharia law introduced in places, a third did not wish their children to be taught alongside non-Muslim children, a quarter were sympathetic to motives of the killers of the "Charlie Hebdo" (French satirical magazine) editor and cartoonists in January 2015, along with a number of other disconcerting attitudes (Phillips et al., 2016).

Although the survey has been subjected to a number of criticisms, the findings are sufficiently striking to create pause for thought in the British social work regarding the question of sensitive (or culturally competent) intervention when working with ME communities. This is particularly necessary when reflecting that such values may be not only distinctively different from the practitioner's own professional and personal value base, but that viewed as generally normative in the dominant society.

\section{Problematized parenting and youth disaffection}

The topic of inculcated cultural values inevitably enters the troubled domain of parenting. The previous authority of and trust in parenting as a private domestic matter of adult responsibility has been much questioned and undermined in the Western world. Although inevitably the film and advertising industries have exploited the idea of questionable parenting in various crass formats, more significantly parenting has also come under the close scrutiny of key government bodies, such as social services, and arguably no more so that in the UK (Fureidi, 2008). However, a culture of blame toward the parenting role is one applied more heavily to certain segments of society over others. Traditional scapegoats include the perceived feckless "underclass," parents with addictions as well as Gypsy Roma and Traveller parents (Scullion \& Brown, 2016). Parental permissiveness that is construed to be taken to a degree of dysfunction also attracts State surveillance; but so too does conservative and religious parenting, where Muslim ME parenting is currently spotlighted as particularly suspicious.

Scourfield and colleagues (2013) observe the importance of religious continuation in British Muslim families where most Muslim children will receive a traditional religious education learning to read the Qur'an in Arabic and imbibing Qur'anic teachings and the Hadith (sayings of Prophet Mohammed, peace be upon him). This is set against a sociopolitical backdrop where Fathi and Hakak (in press) note distrust of the Muslim family, 
mosques, and faith schools as harboring the seeds of Islamist ideologies that are viewed as separatist and inimical to British norms.

The background to these heightened levels of suspicion is a fear of the "enemy within." Unlike $9 / 11$ and the Paris bombings, the 7/7 London bombings were carried out by what was described in media coverage as "four home-grown suicide bombers" (Campbell \& Laville, 2005). Luton, the English hometown of the bombers from which they set off, armed with explosives, is one where there are high levels of self-segregation by the resident South Asian Muslim community. In the case of the Madrid attacks, it was not only the bombings that was so alarming but also the belief that the perpetrators-economic migrants from North Africa (Maghrebians)-were previously assumed to be well-integrated Spanish residents (Jordan, Mañas, \& Horsburgh, 2008).

Additionally, hundreds of young Muslims in the Global North rushed to Syria to join ISIS. While the discovery that "Jihadi John," the self-publicizing, sadistic ISIS executioner, was a British citizen, caused much revulsion and perturbation in the UK. Additional dismay was expressed over the absconding and subsequent disappearance of British Muslim schoolgirls to join ISIS as "jihadist brides," where their parents' shock and grief was widely displayed by the media (Ashencaen Crabtree et al., 2016).

The attraction of young Western Muslims toward extremist causes like ISIS seems deeply puzzling despite or because of its sophisticated use of social media contrasted by crude, turgid propaganda and sickening images. Stern and Berger (2015, p. 3) capture this paradoxical allure as a "strange but potent new blend of utopianism and appalling carnage". The portrayed jihadist struggle nominally seeks to create a global but fundamentalist Wahhabian Sunni caliphate that is exclusive of all other Muslim denominations, duly condemned as Takfir (unbelievers and apostates) together with all non-Muslims (Cockburn, 2014). Regardless of sectarian rationale, youth appeal to Islamist ideologies repudiates dominant cultural values with a distorted veneer of religious justification, bringing the faith into disrepute: "For some youths, the measure of their faith is proportionate to their rejection of the West, as if they defined Islam by what it is not, rather than what it is" (Irfan Coles, 2004, p. 119).

A high level of tension and paranoia is easily whipped up by terrorist events-and here there is a role for social work in the traditional role of mediators working toward strengthening intercommunity cohesion and multicultural, neighborhood solidarity (Popple, 2015). Such work lies beyond the limited, and arguably deskilling, protocol of formal social services, social work assessment, and service provision (Penhale \& Parker, 2008). In the absence of taking up this important, undervalued, professional role such fears have fed into a political Far Right discourse against immigration in the UK. 
Furthermore, throughout Europe there are widespread fears that migration will lead to cultural usurpation rather than social integration, and these views are severely damaging multicultural and humanitarian ideals. A case in point is the severe criticism levied against German Chancellor, Angela Merkel's "Willkommenskultur" open door policy toward mass migration, which has seen a million refugees of different ethnicities and faiths enter Germany in 2015. Such a grand, liberal gesture has since returned to haunt Germany.

\section{Counterterrorism UK-style}

The UK's response to real and potential terrorist attacks has not been complacent or tardy. Following 9/11, the UK reacted in the most extreme way of the European by invoking of a state of emergency in order to pass the Anti-Terrorism, Crime and Security Act (Poynting \& Mason, 2006). While around that time the British Crime Survey showed that South Asian groups of primarily Muslim background were considerably more likely to be the victims of crime than Black, White, or Indian Britons (Ashencaen Crabtree et al., 2016). With the securitization agenda focusing on young Muslims, recent research findings also show that some individuals have adapted their habits and appearances to avoid being identified as Muslims. This too, is of concern to social work, as fundamentally oppressive to people's sense of self and thus their personal integrity.

The UK's counterterrorist strategy, CONTEST, contains an important element targeting so-called "radicalization" of Muslim youth toward violent Islamist cause (Awan \& Guru, 2017). This is the "Prevent" strategy, which is designed to work across a range of institutions and statutory provisions in identifying vulnerable youth-and, thus, of necessity implicates social work, although this is not specifically highlighted (HM Gov, 2015). Accordingly there is a clear, if highly controversial, legal expectation that schools and institutes of higher education comply with the Prevent program through scrutiny of their student body, adding an unwelcomed policing role to that of educator (HM Gov, 2015).

Simultaneously, educational institutions are now expected to actively promote "British" values, another contested notion and area of debate, where such values are said to include the conventional list of tolerance, democracy, individual liberty, and the rule of law, although what distinguishes this from many other democratic states is unclear (Ashencaen Crabtree, in press).

Furthermore, the Prevent strategy has also targeted parents (with an unspoken assumption that this is relevant to Muslim ME parents) to show allegiance to the State by placing an onus on them to police their children and apply to have their passports removed if they suspect planned absconding to terrorist groups (HM Gov, 2015). To fail to do so in this event would 
be to regarded as complicity and irresponsible parenting as well as being guilty of failing to inculcate proper British citizenship values in progeny (Ashencaen Crabtree, in press).

The Prevent program is arguably flawed in conception, insidious in intention, and dangerous in implementation. For to be "radical" is now implicitly associated with subversive violent extremism; to be in effect an "enemy of the state" (to quote the 19th century novelist Conrad).

A construction of the notion of radical as fundamentally subversive and dangerous, as well as being necessarily linked to ideologies of violence, is misconceived, alienating, and therefore risky. One surely expects young people to hold some extreme views, as did the now elderly Baby Boomers in their time. Radical views do not necessarily lead to violent actions and can often lead to important and much needed change as history teaches us. Being able to hold radical views at any age in a democratic society, without inciting in turn extreme State responses, can act as a much needed social safety valve and challenge unquestioned assumptions and prejudices. The fear is, therefore, that the effective outlawing of radicalization leads to a deepening sense of social exclusion and creates the danger of a self-fulfilling prophecy.

In this matter, a sense of proportion is vital to evaluate the perceived threat of "radicalization" among Muslim youth, in which approximately only 700 Britons have travelled to Syria from a British Muslim population of 2.7 million, amounting to a mere $0.026 \%$ of the self-identifying Muslim population (BBC, 2015).

Furthermore, while the State seeks to protect itself from the risks of global terrorism through reactionary counterterrorist measures, in so doing it creates new victims. Guru's illuminating qualitative study from a social work perspective of the impact of counterterrorism on the families of suspected terrorists offers a rare insight into less considered examples of terrorization and vulnerability.

The kids were frightened-crying ... screaming. They even wet themselves standing. They were so scared when they saw their father on the floor ... Even the older ones urinated themselves because they were so scared. I tried to reassure them that he would be back soon ... but I could not stop them crying ... (Guru, 2012, p. 1166).

While social work usually and rightly focuses on the vulnerable, Guru argues that the profession cannot operate within a sanitized moral vacuum that fails to engage with the sociopolitical conditions of people's lives and how these intersect and collide with macro structures and policies. Practitioners are urged to deconstruct and reconstruct what may constitute vulnerability and oppression within a broader discourse of individual circumstances and material realities. 


\section{Concluding remarks}

The concept of vulnerability is loaded with implications in British social work, particularly in relation to eligibility criteria for services. Who is, therefore, deemed to be vulnerable is a political question as much as a social and welfare one (Penhale \& Parker, 2008). A key example is that the White victims of the Rotherham and Rochester abuse cases were largely classified as wilfully wayward rather than vulnerable, exploited minors (Jay Report, 2014). A further example refers to the wives and children of suspected terrorists, as Guru (2012) indicates, who are the invisible victims of State protection of the political and civic body. Finally, the sociodemographics of British ME Muslims clearly indicates higher rates of poverty and lower rates of social participation than among the general population, thus indicating a level of vulnerability that has negative consequences for families and communities, which in turn may lead to a sense of threatening social and civil disenfranchisement along with distrust of government agendas.

Islamophobia, however defined or experienced, is condemned by a profession concerned with antidiscriminatory practice (Thompson, 2005), yet this is also a strong factor in creating alienation and disaffection among secondgeneration Muslim migrants (Kundnani, 2009). It would appear that the government response to vulnerability created by social exclusion has been to interpret it as a radicalized threat to the State and its vulnerable nonradicalized citizens (HM Gov, 2015). Muslim ME parents are, therefore, caught between the hammer and the anvil at this juncture, where firstgeneration Muslims have often strived hard to attain British citizenry and way of life, and yet may be viewed as culpable in creating a cradle of discontent rocking their children (Awan \& Guru, 2017)

As this article indicates, working across ME groups in the UK constitutes a highly complex and sensitive terrain for social work practitioners to scrutinize and carefully negotiate in developing interventions that are both cautious and appropriate. For in relation to Muslim ME communities' ambiguity, contradiction, and paradox provide many snares for an unwary social work practice relying on clear markers of what constitutes vulnerability and need, or indeed oppression. This, in turn, directs where social work can and should energetically invest their energies as relevant to strengthening neighborhood democracy (Popple, 2015) or divest the profession of any real influence in local communities.

\section{References}

Anitha, S. and Gill, A. (2009). Coercion, consent and the forced marriage debate in the UK. Feminist Legal Studies, 17, 165-84 
Archer, L. (2003). Race, masculinity and schooling: Muslim boys and education. Maidenhead, UK: Open University Press.

Ashencaen Crabtree, S. (2014). Islamophobia and the Manichean constructions of the "Other": A contemporary European problem. In S. Ashencaen Crabtree (Ed.), Diversity and the processes of marginalisation and otherness: A European perspective (pp. 181-190). London, UK: Whiting \& Birch.

Ashencaen Crabtree, S. (in press). Social work with Muslim communities: Treading a critical path over the crescent moon. In Beth Crisp (Ed.), Routledge Handbook of Religion, Spirituality and Social Work. London, UK: Routledge.

Ashencaen Crabtree, S., Husain, F., \& Spalek, B. (2008). Islam \& social work: Debating values and transforming practice. Bristol, UK: Policy Press.

Ashencaen Crabtree, S., Husain, F., \& Spalek, B. (2016). Islam \& social work: Culturally sensitive practice in a diverse world (2nd ed.). Bristol, UK: Policy Press.

Ashencaen Crabtree, S., \& Williams, R. (2011). Ethical implications for research into inclusive education in Arab societies: Reflections on the politicisation of the personalised research experience. International Social Work, 8, 1-14.

Awan, I., \& Guru, S. (2017). Parents of foreign "terrorist" fighters in Syria-Will they report their young? Ethnic \& Racial Studies, 40(1), 24-42. doi:10.1080/01419870.2016.1206588

Bangstad, S., \& Bunzi, M. (2010). Anthropologists are talking about Islamophobia and anti-Semitism in the New Europe. Ethnos: Journal of Anthropology, 75(2), 213-228. doi: $10.1080 / 00141841003764021$

BBC. (2006, September 4). One in 10 "backs honour killings". Retrieved from http://news.bbc. co.uk/2/hi/uk_news/5311244.stm

BBC. (2015, December 9). Paris attacks: What happened on the night. Retrieved from http:// www.bbc.co.uk/news/world-europe-34818994

BBC. (2016, January 18). Muslim women's segregation in communities must end-Cameron. Retrieved from http://www.bbc.co.uk/news/uk-35338413

Bucci, L. (2012). An overview of the legal and cultural issues for migrant Muslim women of the European Union: A focus on domestic violence and Italy. Crime, Law \& Social Change, 58, 75-92. doi:10.1007/s10611-012-9370-5

Campbell, D. and Laville, S. (2005, July 13). British suicide bombers carried out London attacks, say police. The Guardian. Retrieved from www.theguardian.com/uk/2005/jul/13/ july7.uksecurity6

Care Standards Act. (2000). Legislation. Gov.UK. Retrieved from http://www.legislation.gov. uk/ukpga/2000/14/pdfs/ukpga_20000014_en.pdf

CEOP (Child Exploitation and Online Protection) Centre. (2011). Out of mind, out of sight: Breaking down the barriers to understanding child sexual exploitation. London, UK: Author.

Christafis, A., Fischer, S., \& Oxley-Rice, M. (2016, July 15). France stunned after truck attacker kills 84 on Bastille Day in Nice. The Guardian. Retrieved from https://www.theguardian. com/world/2016/jul/15/nice-attack-leaves-84-dead-and-france-in-shock

Cockburn, P. (2014). The rise of the Islamic State: ISIS and the new Sunni revolution. London, UK: Verso.

Coffey, A. (2014). Real voices: Child exploitation in Greater Manchester. Retrieved from http:// anncoffeymp.com/wp-content/uploads/2014/10/Real-Voices-Final.pdf

Dominelli, L. (2002). Feminist social work theory and practice. Houndsmill, Basingstoke, UK: Palgrave Macmillan.

Faizi, N. (2001). Domestic violence in the Muslim community. Journal of Women and the Law, 10(2), 15-22.

Fathi, M., \& Hakak, Y. (in press). Muslim parenting in the west: A review. Sociology Compass. 
Fenton, S., \& Sadiq-Sangster, A. (1996). Culture, relativism and the expression of mental distress: South Asian women in Britain. Sociology of Health \& Illness, 18(1), 66-85. doi:10.1111/shil.1996.18.issue-1

Fleischman, F., Phalet, K., \& Klein, O. (2011). Religious identification and politicization for political Islam and political action among the Turkish \& Moroccan second generation in Europe. British Journal of Social Psychology, 50, 628-648. doi:10.1111/j.20448309.2011.02072.x

Forster, K. (2016). Hate crimes soared by 40\% after Brexit vote, official figures reveal. The Independent. Retrieved from http://edition.cnn.com/2016/11/10/us/post-election-hatecrimes-and-fears-trnd/

Frost, D. (2012). Islamophobia: Examining causal links between the state and "race hate" from "below." International Journal of Sociology, 28(11/12), 546-563.

Fureidi, F. (2008). Paranoid parenting. Chicago, IL: Chicago Review Press.

Geisser, V. (2010). Islamophobia: A French specificity in Europe? Human Architecture: Journal of the Sociology of Self-Knowledge, VIII(2), 39-46.

Gohir, S. (2013). Unheard voices: The sexual exploitation of Asian girls and young women. Birmingham, UK: Muslim Women's Network.

Grosfoguel, R., \& Mielants, E. (2006). The long-durée entanglement between Islamohpobia and racism in the modern/colonial capitalist/patriarchal world-system. Human Architecture: Journal of the Sociology of Self-Knowledge, V(I), 1-12.

Gündüz, Z. Y. (2010). The European Union at 50-Xenophobia, Islamophobia and the rise of the Radical Right. Journal of Muslim Minority Affairs, 30(1), 36-47. doi:10.1080/ 13602001003650598

Guru, S. (2012). Under siege: Families of counter-terrorism. British Journal of Social Work, 42, 1151-1173. Advance Access. doi:10.1093/bjsw/bcs089

Heaslip, V., Hean, S., \& Parker, J. (2016). The etemic model of Gypsy Roma community vulnerability: Is it time to rethink our understanding of vulnerability? Journal of Clinical Nursing. doi:10.1111/jocn.13499

Heath, A., \& Li, Y. (2014). Reducing poverty in the UK: A collection of evidence reviews. Joseph Rowntree Foundation. Retrieved from https://www.jrf.org.uk/sites/default/files/jrf/ migrated/files/Reducing-poverty-reviews-FULL_0.pdf

Hill Collins, P. (1998). Intersections of race, class, gender and nation: Some implications for Black family studies. Journal of Comparative Family Studies, 29, 27-36.

HM. Government. (2015). Revised prevent duty guidance for England and Wales. Retrieved from https://www.gov.uk/government/publications/prevent-duty-guidance

Hussain, Y., \& Bagguley, P. (2012). Securitized citizens: Islamophobia, racism and the 7/7 London bombings. The Sociological Review, 60, 715-734. doi:10.1111/j.1467954X.2012.02130.x

Irfan Coles, M. (2004). Education and Islam: A new strategy. In B. van Driel (Ed.), Confronting Islamophobia in educational practice (pp. 111-128). Stoke-on-Trent, UK: Trentham Books.

Jay, A. (2014). Independent inquiry into child sexual exploitation in Rotherham 1997-2013. Rotherham Metropolitan Borough Council. Retrieved from http://www.rotherham.gov.uk/ downloads/file/1407/independent_inquiry_cse_in_rotherham

Jordan, J., Mañas, F. M. and Horsburgh, N. (2008). Strengths and weaknesses of grassroot jihadist networks: The Madrid bombings. Studies in Conflict and Terrorism, 31(1): 17-29.

Kundnani, A. (2009). Spooked! How not to prevent violent extremism. London, UK: Institute of Race Relations. 
Kunst, J. R., Tajamal, H., Sam, D. L., \& Ulleberg, P. (2012). Coping with Islamophobia: The effects of religious stigma on Muslim minorities identity formation. International Journal of Intercultural Relations, 36, 518-532. doi:10.1016/j.ijintrel.2011.12.014

Laird, L. D., Amer, M. M., Barnett, E. D. and Barnes. L. L. (2007). Muslim patients and health disparities in the UK and US. Archives of Diseases in Childhood, 9(10), 922-6

Lorente, J. R. (2010). Discrepancies around the use of the term "Islamophobia." Human Architecture: Journal of the Sociology of Self-Knowledge, VIII(2), 115-128.

Malik, K. (2016). Muslims are not a different class of Britons: We're as messy as the rest. The Guardian. Retrieved from http://www.theguardian.com/commentisfree/2016/may/14/mus lims-class-islam-citizen-britain

McAskill, E. (2007, May 23) US Muslims more assimilated than British. The Guardian. Retrieved from https://www.theguardian.com/world/2007/may/23/usa.midterms2006

Modood, T., Berthoud, R., Lakey, J., Nazroo, J., Smith, P., Virdee, S., \& Beishon, S. (1997). Ethnic minorities in Britain: Diversity and disadvantage. London, UK: Policy Studies Institute.

Muslim Council of Great Britain (MCB). (2015). British Muslims in numbers: A demographic, socio-economic and health profile of Muslims in Britain drawing on the 2011 Census. London, UK: Muslim Council of Great Britain.

ONS (Office for National Statistics). (2002). Social focus in brief: Ethnicity 2002. London, UK: Author.

Orme, J. (2001). Gender and community care. Houndsmill, Basingstoke, UK: Palgrave.

Parker, J., \& Ashencaen Crabtree, S. (2014). Ripples in a pond: What do social workers need to know about terrorism? Social Work \& Social Policy in Transition. Retrieved from http:// essential.metapress.com/content/26170w57262444gp/

Parker, J., \& Bradley, G. (2014). Social work practice (4th ed.). London, UK: Sage.

Peach, C. (2006). Muslims in the 2001 Census of England and Wales: Gender and economic disadvantage. Ethnic and Racial Studies, 29(4), 629-655. doi:10.1080/01419870600665284

Penhale, B., \& Parker, J. (2008). Working with vulnerable adults. London, UK: Routledge.

Phillips, T. with Goodhart, D., \& Gower Davies, J. (2016). Race and faith: The deafening silence. Essex, UK: Civitas.

Popple, K. (2015). Analysing community work: Theory and practice. Maidenhead, UK: Open University Press.

Poynting, S. and Mason, V. (2006). “Tolerance, freedom, justice and peace”? Britain, Australia and anti-Muslim racism since 11 September 2001. Journal of Intercultural Studies, 27(4), 365-91.

Pryke, J., \& Thomas, M. (1998). Domestic violence and social work. Aldershot, UK: Ashgate.

Reavey, P., Ahmed, B., \& Majumdar, A. (2006). "How can we help when she won't tell us what's wrong?" Professionals working with South Asian women who have experienced sexual abuse. Journal of Community \& Applied Social Psychology, 16(3), 171-188. doi:10.1002/casp.856

Runnymede Trust. (1997). Islamophobia, a challenge for us all. London, UK: Runnymede Trust.

Schuster-Craig, J. (2015). "Well-integrated Muslims" and adolescent anti-violence activism in Berlin. German Life and Letters, 68(1), 125-144. doi:10.1111/glal.2015.68.issue-1

Scourfield, J., Warden, R., Gilliat-Ray, S., Khan, A., \& Otri, S. (2013). Religious nurture in British Muslim families: Implications for social work. International Social Work, 56(3), 326-342. doi:10.1177/0020872812474032

Scourfield, J. B., \& Coffey, A. (2002). Understanding gendered practice in child protection. Qualitative Social Work, 1(3), 319-340. doi:10.1177/1473325002001003644 
Scullion, L., \& Brown, P. (2016). Understanding the social exclusion of Roma. In A. Ahmed \& M. Rogers (Eds.), Working with marginalised groups (pp. 70-82). London, UK: Palgrave.

Sheridan, L., Gillett, R., Blaauw, E., \& Winkel, F. (2003). Effects of the events of September 11th on discrimination and implicit racism in five religious and seven ethnic groups. Leicester, UK: University of Leicester School of Psychology.

Spiegel Online. (2016, January 8). Chaos and violence: How New Year's Eve in Cologne has changed Germany. Spiegel Online International. Retrieved from http://www.spiegel.de/ international/germany/cologne-attacks-trigger-raw-debate-on-immigration-in-germany -a-1071175.html

Stern, J. and Berger, J. M. (2015). ISIS: The state of terror. London, UK: William Collins.

Taras, R. (2013). “Islamophobia never stands still": Race, religion and culture. Ethnic \& Racial Studies, 36(3), 417-433. doi:10.1080/01419870.2013.734388

Thompson, N. (2005). Understanding social work. Basingstoke, UK: Palgrave Macmillan.

Tickle, L. (2006, October 10). Do not contact the parents. The Guardian. Retrieved from https://www.theguardian.com/education/2006/oct/10/schools.uk

Tripathi, A., \& Yadav, S. (2004). For the sake of honour: But whose honour? "Honour crimes" against women. Asia-Pacific Journal on Human Rights and the Law, 5(2), 63-78. doi:10.1163/157181504774852050

TUC (Trades Union Congress). (2005). End UK Pakistani and Bangladeshi poverty and deprivation (Press release). Retrieved from www.tuc.org.uk/equality/tuc-10401-f0.cfm

Turney, D., Platt, D., Selwyn, J., \& Farmer, E. (2011). Social work assessment of children in need: What do we know? Messages from research. London, UK: Department for Education.

Yan, H., Sgueglia, K., \& Walker, K. (2016). Make America White again: Hate speech and crimes post election. CNN. Retrieved from http://edition.cnn.com/2016/11/10/us/postelection-hate-crimes-and-fears-trnd/ 